Change of Life in Men and Women

By Dr. Marie Carmichael Stopes. Pp. xv +282 . (London: Putnam and Co., Ltd., 1936.) 6s. net.

THIs book, like most others of the author, is popular in style and easy to understand. Moreover, it contains much common sense and a great deal of the advice given is thoroughly sound. For example, no physician would quarrel with the recommendation to avoid constipation. There are many other practical suggestions, and Dr. Stopes has done good service in directing attention to the help to be obtained from the work of the distinguished Spanish gynæcologist, Prof. Gregorio Marañón.

It is in dealing with the male climacteric that Dr. Stopes claims most originality, and though every -medical man will agree with her as to the importance of studying this subject, serious doubts will be expressed as to the value of some of her advice and the accuracy of some of her statements. It is surely an extreme view to hold that "in the general physiology of man the testicles share their pre-eminent place with the prostate gland", and it is by no means certain that "the spermatozoa are stimulated to activity" by the alkalinity of the prostatic secretion. Again, it is doubtful what action the prostatic hormone possesses, or indeed whether there is a true houmone secreted by the prostate at all. Yet Dr. Stopes recommends the use of prostatic extracts to reduce the enlargement to which the prostate is subject. It is stated, further, that these and other extracts should be taken orally and not injected, the fact being ignored that most hormones (but not thyroid) are destroyed in the alimentary canal and never enter the circulation of the patient. In view of recent researches on the testicular hormones, it may confidently be predicted that in course of time, and probably in the near future, prostatic enlargement will be successfully treated, but Dr. Stopes does not allude to testicular extracts ; and in any event further experimental data are required before definite recommendations can be safely made in a book addressed to the general public.

\section{Isles of the Seven Seas}

By Collingwood Ingram. Pp. $283+31$ plates. (London: Hutchinson and Co (Publishers), Ltd., 1936.) 18s. net.

THE author is well known among horticulturists as an enthusiastic collector of cherries, and one who has also contributed to our knowledge of the genus Gladiolus. Furthermore, all his life he has been an observer of birds. Equipped with the twin lore of botany and ornithology, he has travelled widely, collecting and noting. For the purpose of this book, he has made a selection from his copious material, confining himself to islands he has visited. We leap from Tahiti to Coll and back to Sumatra, to Corsica, New Zealand, Ushant, and not least to Little Tobago ; and if we have a feeling that Mr. Ingram is rather self-consciously trying to avoid the too smooth dayto-day narrative of orthodox travel literature, the device has its charm. Wisely he rivets our interest at the start by taking us to the South Seas.
Where the author has, if not quite beaten out the track himself, at least helped to widen it-and nowhere does he follow the crowd-he writes interest. ingly, and with real insight. His account of his father's experiment in introducing a very rare bird of paradise from the Aru Islands into Little Tobago is fascinating. Occasionally he imports scientific words into narrative in a slightly pretentious way; it would indeed be surprising if the moonlight even in Tahiti, where we expect everything to be glamorous, is really 'glaucous'! Such mannerism is the only blemish in an otherwise pleasant style.

The book is a record of personal impressions by a man of considerable feeling and knowledge, trained to observe accurately; a scholarly but not technical book for the lover of Nature.

Eisen- und Stahllegierungen: Patentsammlung Ergänzungsheft 1. Von A. Grützner. Zugleich Anhang zur Metallurgie des Eisens in "Gmelins Handbuch der anorganischen Chemie", achte völlig neu bearbeitete Auflage herausgegeben von der Deutschen Chemischen Gesellschaft. Pp. $\mathrm{v}+425$. (Berlin : Verlag Chemie G.m.b.H., 1935.) 44 gold marks.

THE publication in 1932 of a special volume containing in tabular form a list of patent specifications relating to iron and steel has proved to be so useful to research workers engaged in this industry that it has been necessary to prepare supplements of this collection on similar lines. The comprehensive nature of these tables, which cover the patent specifications of Germany, England, France, Austria, Switzerland and the United States, will be gathered from the fact that the present issue deals only with the interval between March 1932 and December 1934, and furthermore another special supplement to Part A of the volume on iron is being devoted to "Mechanical Properties of Steels", and will contain a complete bibliography extending over a very considerable period of time.

\section{Epitome de Culturologia}

Por el Dr. Imbelloni. (Humanior: Biblioteca del Americanista Moderno, Serie A, Tomo 1.) Pp. $320+$ 8 plates. (Buenos Aires: José Anesi, 1936.) n.p.

THE series, of which this is the first volume, might well be symbolized by an inverted cone. The volumes of which it will be composed are classified into sections, beginning with general surveys of the various branches of the study of man, and narrowing and intensifying with each successive section, until in the sixth and last, attention is focused on the cultural history and ethnology of Argentina. This conception of a gradual intensification of interest as a basis of regional study, if execution does not fall behind, is wholly admirable. Dr. Imbelloni has given the series a good send-off in his survey of the study of culture and the methods of investigation by cultural distributions. Several examples of the study of areas of cultural distribution in relation to specific cultural traits are given in appendixes. 